\title{
Intensive mobilities: Figurations of the nomad in contemporary theory
}

Thomas Sutherland

In The Anti-Christ, Friedrich Nietzsche (2005, page 57) calls for a "becoming" of the individual premised upon "experimentation, the continuation of values in a fluid state, scrutiny, selection, and criticism of values in infinitum" - in short, a rejection of any politics of identity; any presumption of a static essence that underpins an individual. When considering the broader context of the philosophy that he seeks to criticize, and its tendency toward ontologization of normative social categories (from the outright misogyny of Plato and Aristotle onward), it is hard not to sympathize with such a goal. At the same time though, there are perhaps limits to the political utility of this principle of becoming. In an economy premised upon flexibility, circulation, and a constant demand for upskilling - a world of "fast, intensive mobilities," as Anthony Elliott and John Urry (2010, page 22) put it - there is something oddly familiar about submitting ourselves to a perpetual revolution of our own identities and values.

My intention in this essay is to both scrutinize and critique the notion of nomadic subjectivity, which begins in the philosophy of Gilles Deleuze and Félix Guattari, is adopted as a principle of political action in the work of Michael Hardt and Antonio Negri, but has found probably its most successful recent manifestation through philosopher Rosi Braidotti, whose interest in developing a Deleuzian conception of feminist subjectivity coupled with Luce Irigaray's ethics of sexual difference has gradually widened to encompass broader themes such as materiality and posthumanism. My aim is not to challenge the relevance of the problematic of becoming for feminist theory, which has quite reasonably tended to oppose itself to any fixed or essentialist conception of identity, but rather, to ask whether an ontology of becoming tied to the figural posthuman nomad is the best way to challenge structures of domination in an epoch when change, mobility, and flexibility would seem to be closer to hegemonic constructs than ideals of resistance.

\section{The mobility of the nomad: Deleuzian origins}

The question of nomadism is first and foremost connected to issues of mobility. The nomad, as a sociological category, is a wanderer, an itinerant, a peripatetic who does not associate home with fixed place. The very word is derived from the Greek vouás, referring to those who roam in search of pastures for their herds of cattle or flocks of sheep. Paul Virilio (2008, page 25), whose philosophy seeks to historicize and contextualize questions of mobility, argues that historically, we:

find ourselves faced with a sort of great divide in knowing how to be in the world: on the one hand, there is the original nomad for whom the journey, the being's trajectory, are dominant. On the other, there is the sedentary man [sic] for whom subject and object prevail, movement towards the immovable, the inert, characterizing the sedentary urban 'civilian' in contrast to the 'warrior' nomad.

Virilio is deeply critical of the intensified movement and speed of the digitized, networked society, which he views as paradoxically leading us toward an "ultimate state of sedentariness where real-time 
Thomas Sutherland, 'Intensive mobilities: figurations of the nomad in contemporary theory', Environment and Planning D: Society and Space. $32(5): 935-950$.

http://www.envplan.com/abstract.cgi?id=d14027p

environmental control will take over from the development of the real space of the territory." (Virilio 2008, page 25) What defines those of a sedentary lifestyle, therefore, is not so much an absence of movement as a refusal to conceive of the journey as an end in itself. For the sedentary woman or man, movement is always specifically movement toward fixity.

This division between the nomadic and the sedentary is not a particularly new metaphor within philosophy: for instance, in defining the parameters of his transcendental idealism, Immanuel Kant (1998, page 99) speaks dismissively of "the skeptics, a kind of nomads who abhor all permanent cultivation of the soil." Interestingly however, where Kant uses the term in order to denigrate those who reject the notion of stable truths - in Christopher Norris' (1993, page 231) words, skepticism represents for Kant "a state of perpetual exile, an existence deprived of any settled habitation and resigned to the necessity of pitching camp on whatever new terrain it changes to discover" - Deleuze by contrast uses it to celebrate the very same: in Difference and Repetition, he differentiates between two forms of distribution. The former is "a type of distribution which implies a dividing up of that which is distributed" - that is, "it is a matter of dividing up the distributed as such" - whereas the latter, "which must be called nomadic," is "without property, enclosure or measure." (Deleuze, 1994, page 46) In this nomadic distribution, "there is no longer a division of that which is distributed but rather a division among those who distribute themselves in an open space - a space which is unlimited, or at least without precise limits," and therefore, people are distributed within it, rather than distributing it. (page 46) It is "more like a space of play, or a rule of play, by contrast with sedentary space."

As is generally the case, the division Deleuze makes here is principally an analogue for his dyad of the actual and the virtual, in turn directly related to the ancient dyad of being and becoming that originates in the philosophy of Parmenides, and is later formalized by Plato. Nomadic distribution "is not a matter of being which is distributed according to the requirements of representation, but of all things being divided up within being in the univocity of simple presence," (page 46) and as such, it is a form of division as becoming - a creative principle of differentiation irreducible to the representations that constitute experience; it is, in fact, the transcendental condition of the genesis of such experience. The virtual is "a plastic, anarchic and nomadic principle, contemporaneous with the process of individuation, no less capable of dissolving and destroying individuals than of constituting them temporarily," which always exists in excess of that which is actual, "circulating and communicating underneath matters and forms." (page 47) Within Deleuze's philosophy, this is therefore a selfevidently metaphysical dualism, by which he distinguishes between the sedentary entities that constitute empirical experience, and the nomadic differences from which these entities are actualized.

It is telling that nomadism has gradually been transformed from a term of derogation to one of valorization without its content really changing much at all - to quote Norris (1993, page 231) once again, nomadism represents for Deleuze "a thinking that abandons the security of method and system," producing "intensities of impulse and desire that would offer... a route of escape from this authoritarian regime of truth, knowledge and representation." This shift is even clearer in Deleuze's collaborations with Guattari (1994, page 109), wherein they argue that "the race summoned forth by art or philosophy is not the one that claims to be pure but rather an oppressed, bastard, lower, anarchical, nomadic, and irremediably minor race - the very ones that Kant excluded from the paths of the new Critique." Within A Thousand Plateaus in particular, the image of the nomad is deployed frequently and multivalently, in uses ranging from literal discussions of nomadic populations, to diverse 
Thomas Sutherland, 'Intensive mobilities: figurations of the nomad in contemporary theory', Environment and Planning D: Society and Space. $32(5): 935-950$.

http://www.envplan.com/abstract.cgi?id=d14027p

political and metaphysical analogies. For the most part, however, the notion of nomadism remains largely within the definitional boundaries established within Deleuze's solo works, albeit with a political and ethical dimension that is largely absent in those earlier writings. "History is always written from the sedentary point of view," argue Deleuze and Guattari (1987, page 25), "and in the name of a unitary State apparatus, at least a possible one, even when the topic is nomads. What is lacking is a Nomadology, the opposite of a history."

In this spirit, nomadism tends to utilized as a metaphor for those forces that always remain in excess of their organization. At an ontological level, Deleuze and Guattari (1987, page 45) propose that the body without organs - the hyperdifferentiated plane of consistency opposed to the organism - is "permeated by unformed, unstable matters, by flows in all directions, by free intensities or nomadic singularities, by mad or transitory particles." Such nomadic singularities, in other words, are equivalent to the intensive differences that compose the virtual in Deleuze's own philosophy. In regard to the theoretical sciences, they argue that there is an eccentric nomad science "that is very different from the royal or imperial sciences," and which is "continually 'barred,' inhibited, or banned by the demands and conditions of State science." (page 399) In the case of differential calculus, for instance, a topic that Deleuze comes back to frequently throughout his oeuvre, they argue that "the great State mathematicians did their best to improve its status, but precisely on the condition that all the dynamic, nomadic notions - such as becoming, heterogeneity, infinitesimal, passage to the limit, continuous variation - be eliminated," resulting in a relative paucity of interest in questions of fluidity and turbulence, in contrast to the "hydraulic model of nomad science." (pages 400-401) Where royal science "aspires to universality," its nomadic counterpart "does not ground itself in an all-encompassing totality but is on the contrary deployed in a horizonless milieu that is a smooth space, steppe, desert, or sea." (page 418)

Whilst I will return to this point when discussing Irigaray, probably most important for our present purposes is the more directly political line of argument, in which the assemblage that they refer to as the "war machine," which is "of nomadic origin and is directed against the State apparatus," is posed against the State, which strives with great difficulty to "appropriate this war machine that is foreign to it and make it a piece in its apparatus, in the form of a stable military institution." (page 253) Whereas the State operates on the basis of capture, harnessing the flows of smooth space to specific ends, and thus striating it through division and hierarchy, the nomads, who "have absolute movement," operate on the basis of a war machine that always avoids such capture, thus opposing itself to all organization. (page 321) Although such nomads are liable to become migrants, transhumants, or itinerants, none of these descriptions are essential to their nature, for "the primary determination of nomads is to occupy and hold a smooth space." (page 475) Crucially, nomadism is not a practice that exists prior to sedentariness; rather, "nomadism is a movement, a becoming that affects sedentaries, just as sedentarization is a stoppage that settles the nomads." (page 475) The State is reliant upon the smooth space engendered and preserved by the nomads, in the same way that the war machine is reliant upon the organization of the State to which it is opposed.

Justin Clemens (2003, page 148) maintains that Deleuze and Guattari's "founding gesture itself takes place on the ground of a strict covert identification of authority with organization, and organization with oppression," so that free-moving, anarchistic becoming is necessarily privileged and valorized over static, ordered being. Although this would be a fair statement to make if summarizing 
Thomas Sutherland, 'Intensive mobilities: figurations of the nomad in contemporary theory', Environment and Planning D: Society and Space. $32(5): 935-950$.

http://www.envplan.com/abstract.cgi?id=d14027p

Deleuze's philosophy in one swathe, in A Thousand Plateaus specifically, a lot more caution is shown in regard to this particular problematic. Although they are still happy to present becoming as prior to being (with all the problems that this implies), positing "the creation of the world from chaos, a continual, renewed creation," (page 553) they are far more hesitant in attaching normative value to becoming as a limit. "Staying stratified," they observe (page 178), “- organized, signified, subjected - is not the worst that can happen; the worst that can happen is if you throw the strata into demented or suicidal collapse, which brings them down on us heavier than ever," a far more conservative statement than they are perhaps often given credit for, especially when compared to the claims made in AntiOedipus (1983).

At the same time though, it would seem hard to argue with the observation that nomadism not only remains ontologically privileged within their work (effectively adopting the role of Deleuze's virtual), but that it is politically romanticized also, falling directly into a trend that Tim Cresswell (2006, page 46), one of the most percipient critics of the fetishization of mobility, identifies:

the willing embrace of metaphors of mobility generated within poststructural and nonrepresentational philosophies ranging from Maurice Merleau-Ponty's phenomenology of bodily perception to Deleuze and Guatarri's rhizomatics and nomadology. Mobility has become the ironic foundation for anti-essentialism, antifoundationalism and antirepresentationalism. While place, territory, and landscape all implied at least a degree of permanence and flexibility, mobility seems to offer the potential of a radical break from a sedentarist metaphysics.

As Cresswell (page 47) goes on to explain, key to nomadic metaphysics "is the idea that by focusing on mobility, flux, flow, and dynamism we can emphasize the importance of becoming at the expense of the already achieved - the stable and static," the former of which is of course linked to a realm of embodied praxis - "of anti-essentialism, anti-foundationalism, and resistance to established forms of ordering and discipline" - distinct from the staid abstractions of traditional philosophy.

There is a strong ethics of identity contained within this concept of nomadism, within which two distinct, albeit closely related perspectives come together. The first, as noted in the introduction, is Nietzsche's concept of perpetual revolution of the self - the overman who seeks to overcome humanity, to transvaluate all values, to subject all preconceptions to constant critique. This is becoming, in other words, as an ethical demand. The second is Henri Bergson's (1911, page 128) contention that "[1]ife in general is mobility itself; particular manifestations of life accept this mobility reluctantly, and constantly lag behind," which understands freedom as being a product of the intuition as opposed to the intellect, the latter of which cannot only understand movement in spatial, divisible, and thus static terms. In short, for Bergson - demonstrating an astounding lack of trust in the categories of critical reason - true freedom would require a complete rejection of abstract conceptuality, in favour of the fluid becoming of one's own durée. Both of these perspectives are combined in Deleuze's (1994, page 334) celebration of "the state of free, oceanic differences, of nomadic distributions and crowned anarchy," and are central to many post-Deleuzian perspectives on nomadism as political and theoretical praxis, which I will now move on to discuss.

\section{Braidotti's nomadic subjectivity}


Thomas Sutherland, 'Intensive mobilities: figurations of the nomad in contemporary theory', Environment and Planning D: Society and Space. $32(5): 935-950$.

http://www.envplan.com/abstract.cgi?id=d14027p

There are numerous theorists who utilize Deleuze and Guattari's take on nomadism, and as such, I will not make any claims to comprehensive coverage of the topic. Nonetheless, there are a few in particular who stand out in terms of their import for this debate. Hardt and Negri (2000, page 61) argue that Empire - the diffuse, global power structure that they view as ending the unquestioned dominance of nation-states - has engendered a "universal nomadism." The "new transversal mobility of disciplined labor power is significant," they argue, "because it indicates a real and powerful search for freedom and the formation of new, nomadic desires that cannot be contained and controlled within the disciplinary regime," so that in effect, the increasingly mobile workforce that globalized capital depends upon is providing the means for the latter's dissolution - although they admit that there are many negative consequences arising from this mobility, they suggest that it is worth it in exchange for "the increased desire for liberation." (page 253)

This celebration of free movement and its liberatory potential is not an isolated occurrence; on the contrary, it is indicative of a larger "mobility turn" within the social sciences that claims to problematize "both 'sedentarist' approaches in the social science that treat place, stability and dwelling as a natural steady-state, and 'deterritorialized' approaches that posit a new 'grand narrative' of mobility, fluidity or liquidity as a pervasive condition of postmodernity or globalization.” (Hannan, Sheller, Urry 2006, page 5) It is the latter problem, typified by the concept of nomadism, that I believe requires further analysis and critique, for as Cresswell (2010, page 18) notes, "[a] study of mobility runs the risk of suggesting that the (allegedly) immobile notions such as boundaries and borders, place, territory, and landscape is of the past and no longer relevant to the dynamic world of the 21 st century," thus potentially eliding the multifarious diversity of possible movements - Cresswell (page 26) identifies six facets of mobility, all of which have a political dimension: "the starting point, speed, rhythm, routing, experience, and friction" - and foreclosing the possibility that stability and even permanence (being, rather than becoming) offer their own valuable contributions to political praxis.

In a suspiciously dialectical move (in spite of their typically Deleuzian disavowal of such), Hardt and Negri make the audacious claim that "throughout the ontological terrain of globalization the most wretched of the earth becomes the most powerful being, because its new nomad singularity is the most creative force and the omnilateral movement of its desire is itself the coming liberation." (page 363) This is a conceptual framework in which mobility is not only equated with political freedom, but with an ontological productivity of desire - "the intrinsic power of desire to create its own object," as Deleuze and Guattari (1983, page 27) would have it - that ensures that this freedom, as expressed through the creative potential of immaterial labour, always exceeds its reification by the forces of capital. It is a surplus that always overflows, producing a global commonality that at once constitutes and undermines the power of Empire. We see similar themes also in the work of Eugene W. Holland (2011, page 8), who argues that "[p]olitical philosophy in the deterritorialized social milieu of the world market" demands "a correspondingly deterritorialized form of citizenship, nomad citizenship." In both cases, the compulsory cosmopolitanism of a nomadic labour force is presented as engendering a new form of political engagement, beyond the stratifications of the state, which captures and domesticates the multitude's inherent creativity.

Holland seeks to go beyond Hardt and Negri though, who he views as still beholden to an outdated model of revolutionary struggle in which the demand to enact social change is perpetually deferred in fidelity to an always imminent, but never arriving revolutionary event that will once and for 
Thomas Sutherland, 'Intensive mobilities: figurations of the nomad in contemporary theory', Environment and Planning D: Society and Space. $32(5): 935-950$.

http://www.envplan.com/abstract.cgi?id=d14027p

all abolish state power and transform the relations of production. Instead, Holland (2011, page 152) proposes an "affirmative nomadology," whereby one does not need to wait in deference to the comingrevolution, for "alternative nomadic groups, practices, and institutions already exist, and the imperative is to sustain and develop them directly and without delay," the result being that the existing social order is not entirely overthrown, but rather, is gradually displaced. What is notable, however, is that in spite of their variances, what is agreed upon in these two accounts is that nomadism is neither something still-to-come, nor something that is external to the operations of capital; instead, as with Holland, Hardt and Negri (2000, page 276) argue that the reorganization of Western society in its transition from an industrial to post-industrial economy was driven by the changing subjectivity of the proletariat, rather than the top-down needs of a ruling class, and as such, "the truly creative moment had already taken place," with capital placed in the position of merely seeking "to dominate a new composition that had already been produced autonomously and defined within a new relationship to nature and labor."

The primary philosopher of interest here, however (other than Deleuze), is Braidotti (2013, page 43), who also criticizes Hardt and Negri for their tendency to "avoid science and technology and not to treat it with anything like the depth and sophistication that they devote to the analysis of subjectivity" - almost certainly a fair assessment, albeit one beyond the scope of this essay. Nevertheless, what Braidotti (2006b, pages 1, 195-196) shares with both Hardt and Negri and Holland is a dedication to the concept of nomadic subjectivity, which she directly opposes to both "the technologically driven historical phase of advanced capitalism" and "a phallogocentric scheme of signification." Arguing the need to rethink political praxis within the context of "a reorganization of capital accumulation in a transnational mobile manner," Braidotti (1994, pages 2, 4) offers the nomad as a figural presentation of "a situated, postmodern, culturally differentiated understanding of the subject in general and of the feminist subject in particular," which allows her to "think through and move across established categories and levels of experience" through a deliberate process of mythmaking which she claims offers "a way to step out of the political and intellectual stasis of these postmodern times."

"The radical nomadic epistemology Deleuze and Guattari propose is a form of resistance to microfascisms," Braidotti (page 5) suggests, "in that it focuses on the need for a qualitative shift away from hegemony, whatever its size and however 'local' it may be." The nomad, she reassures us, is not a literal figure, but on the contrary, is a mythical figuration of the kind of critical, theoretical engagement that refuses to remain both entrenched within conventional, stagnatory modes of thought and attached to the ancient authority figures that still preside over philosophical discourse. Nomadism designates "a creative sort of becoming" that enables new encounters to occur and new concepts to arise: the nomadic subjects she speaks of are "capable of freeing the activity of thinking from the hold of phallocentric dogmatism, returning thought to its freedom, its liveliness, its beauty." (pages 6, 8) They refuse to be interpellated into any hegemonic, restrictive, or permanent subject-position, whilst at the same time avoiding the utter dissolution of identity. Nomadism is a deconstruction (or perhaps more accurately, a continual move toward deconstruction, given the impossibility of a distinct terminus to such a process) rather than the destruction of identity: "not fluidity without borders but rather an acute awareness of the nonfixity of boundaries... the intense desire to go on trespassing, transgressing." (page 36)

References to mobility as a principle of freedom and creativity are once again frequent and overt: "nomadism," Braidotti (pages 16, 22) offers, "consists not so much in being homeless, as in being 
Thomas Sutherland, 'Intensive mobilities: figurations of the nomad in contemporary theory', Environment and Planning D: Society and Space. $32(5): 935-950$.

http://www.envplan.com/abstract.cgi?id=d14027p

capable of recreating your home everywhere," being a "figuration for the kind of subject who has relinquished all idea, desire, or nostalgia for fixity." The nomad is continually moving, circulating, making connections: she or he is not transient, for that would imply the kind of self-interested individualism that Braidotti explicitly rejects, but is transitory: always moving, but always returning, constituting a repetition in, as Deleuze (1994, page 3) puts it, "the name of a power which affirms itself against the law, which works underneath laws, perhaps superior to laws." The stress that Braidotti (1994, page 256) places upon mobility is connected to the historical subjugation of women through the imposition of fixity: "[f] rom Aristotle to Freud woman has been described as immobile, that is to say passive, or quite inactive," and thus, feminine subjectivity is rendered dependent. In such a context, mobility "is something new and exciting for women." (page 256) Against this immobility, consistently reinforced through the dualistic hierarchies of Western metaphysics, Braidotti (page 169) poses the feminist subject, which "is nomadic because it is intensive, multiple, embodied, and therefore perfectly cultural," as the starting-point of the "post-Woman" woman. It is through the deconstructive process of nomadism that feminists may begin to negotiate and attempt to come to terms with hegemonic representations of sexual difference.

In her early work, this question of female subjectivity is the primary focus of Braidotti's philosophy. In her more recent writings, however, she begins to follow one of her key influences, Donna Haraway - whose thought she depicts as her "travel companion across multiple nomadic paths of reflection and practice" (2006a, page 197) - in beginning to trace broader questions related to posthumanism, seeking to contest "the arrogance of anthropocentrism" through a "vital materialism" that refuses to accept the primacy of the human as transcendental subject, and instead seeks life in its manifold manifestations. (2013, page 66) Such a theory, she argues, strives toward "an enlarged sense of inter-connection between self and others, including the non-human or 'earth' others, by removing the obstacle of self-centred individualism," and encouraging a mode of subjectivity that breaks out of the ossified regimes of thought that have evolved from the liberal humanism of the Age of Enlightenment. (pages 49-50) The scope of nomadic subjectivity here is widened far beyond questions of female identity, challenging the entire notion of what it means to be human.

The political import of this challenge is, of course, immense, and once again, Braidotti (page 92) makes it clear where her allegiances lie: nomadism, she argues, sets "the framework of recomposition of bodily materiality in directions diametrically opposed to the spurious efficiency and ruthless opportunism of advanced capitalism." Although he does not discuss her work, Braidotti's nomadic theory would seem to me to be a paradigmatic example of that which Benjamin Noys (2010, page 13) terms affirmationism, a form of argument common within recent continental philosophy, which attempts to "provide a solution to articulating agency in the context of an ontology of capital that operates through the voiding of content and the distribution of differences" by "insisting on the need for a positive point of orientation to truly disrupt the void or absence of determinations at the heart of capitalism." In the case of Braidotti, as with Deleuze, this affirmation occurs through the insistence upon an ontology of desire - that is, of intensive difference - which lies in surplus of all social stratifications, and hence all extensive differences produced on the basis of representation. "Affirmative ethics," Braidotti (2013, page 129) proposes, "is based on the praxis of constructing positivity, thus propelling new social conditions and relations into being, out of injury and pain." Nomadism, as an ethics of creativity, produces positives out of negatives - it is the transformation of sexual difference "from sedentary logocentric thinking to nomadic creative thought." (Braidotti 1994, page 30) 
Thomas Sutherland, 'Intensive mobilities: figurations of the nomad in contemporary theory', Environment and Planning D: Society and Space. $32(5): 935-950$.

http://www.envplan.com/abstract.cgi?id=d14027p

\section{Fluidity in Irigaray}

Such affirmation, Braidotti (1994, page 30) remarks, is formulated on the basis of a practice that "both Irigaray and Deleuze defend as a form of creation of new ways of thinking." In a great deal of her work, Irigaray seeks to effectively reread the Western canon of philosophy through the lens of sexual difference, in order to demonstrate the fundamentally masculinist framework within which this discourse operates - this is, in effect, a feminist reconceptualization of Deleuze and Guattari's nomad science. Utilizing an unusually strident form of strategic essentialism, she argues that philosophical and scientific discourses are themselves premised upon a systematic exclusion of the feminine; that they mirror "a society that has simultaneously used and excluded" women, giving them no voice of their own. (Irigaray 1985, page 127) One example of this is the way in which consideration of fluidity has purportedly been occluded and obfuscated within the study of physics: "historically," she suggests (page 116), "the properties of fluids have been abandoned to the feminine," the result being that the real dynamics of nature are excluded from the sciences' calculations, producing a rigid, abstract understanding of the world, abstracted from the materiality upon which it is grounded. "Solid mechanics and rationality have maintained a relationship of very long standing, one against which fluids have never stopped arguing." (page 113)

It is not so much that fluid mechanics have been ignored - there is a long history of exactly this going back at least as far as Archimedes, not to mention the philosophy of Lucretius, which Michel Serres (2000) proffers as the first scientific model of turbulence - but rather, that it is firstly perpetually subordinated to the study of solid mechanics, which fit more precisely the worldview of masculinist rationality, and secondly studied in a way that elides its very fluidity, because "only the idealizable characteristics of fluids are included in their mathematicization":

considerations of pure mathematics have precluded the analysis of fluids except in terms of laminated planes, solenoid movements (of a current privileging the relation to an axis), spring-points, well-points, whirlwind-points, which have only an approximate relation to reality (Irigaray 1985, page 109).

The laminar flow is characteristic of this, being smooth, constant, free of turbulence, and utterly idealized - as Serres (2000, page 7) asks: "Who can fail to see that a flow does not remain parallel for long, who can fail to see that a laminar flow is merely ideal and theoretical?" It is not only physics, however, that succumbs to this tendency: philosophy as a whole, Irigaray (1999, page 3) purports, in its elision of materiality in favour of form, suffers from an "inability to translate fluid realities into discursivity." For Serres (2000: 29; see also Cresswell and Martin 2012), it is only through Lucretius' atomism that the tradition of metaphysics momentarily swerves toward "these areas abandoned by Platonic geometricism... the temporarily metastable leaning and whirling, the concrete contradiction, the turbo of the top, unstable, immobile and mobile."

What is immediately noticeable is that Irigaray is (at least superficially) not really relying upon a metaphor of fluidity, but instead, is seeking to criticize the way in which actual fluids are studied and discussed. Yet there is also a metaphorical side to her argument, one that takes particular elements of male and female physiology (menstrual fluids, for instance) and attempts to provide an essentialized understanding of discourse on their basis. There is an intentional playfulness here in the way that 
Thomas Sutherland, 'Intensive mobilities: figurations of the nomad in contemporary theory', Environment and Planning D: Society and Space. $32(5): 935-950$.

http://www.envplan.com/abstract.cgi?id=d14027p

Irigaray attempts to mimic the very discourses that she seeks to undermine: this is a deliberate strategy, a form of feminist affirmationism in which one must "assume the feminine role deliberately" in order to "convert a form of subordination into an affirmation, and thus to begin to thwart it" (Irigaray 1985, page 76). One deliberately enters discourse in the role of the excluded feminine in order to identify and mobilize that necessary absence as agency. This project of mimesis is presented in opposition to more typical forms of feminist protest, in which (she asserts), one is forced to speak as a masculine subject, thus entrenching the rationalist elision of sexual difference.

For Irigaray, masculinist discourse smooths out the turbulences (i.e. differences) that necessarily exist within any fluid or becoming. For instance, at one point she criticizes Deleuze and Guattari's conception of the desiring-machine, arguing that it expresses nothing other than the harnessing or exploitation of a feminine desire that is unable to exercise its own agency except as an adjunct to the masculine subject. Accordingly, she suggests that a perceived organlessness - a bodily absence - is the historical condition of women, thus making the body-without-organs a masculine appropriation which once more risks "taking back from woman those as yet unterritorialized spaces where her desire might come into being." (page 141) In both cases, the flow of desire through which sexual differentiation can be understood is captured by a universalizing discourse that operates precisely through the occlusion of this difference.

For many scholars emerging out of the poststructuralist tradition, remarks Philip Steinberg (2013, page 158), the ocean "is reduced to a metaphor: a spatial (and thereby seemingly tangible) signifier for a world of shifting, fragmented identities, mobilities, and connections," and this could not be exemplified better by Irigaray (1991, page 37), who claims that there is "no peril greater than the sea," for "everything is constantly moving and remains eternally in flux." It is not that the metaphysical tradition ignores this becoming but rather, that it refuses to accept the mutual necessity of both the land and the sea, being and becoming: from Parmenides onward, philosophy tends to "think of the sea from afar, to eye her from a distance, to use her to fashion the highest reveries, to weave his dreams of her, and spread his sails while remaining safe in port." (page 51). We see this in Plato (2005, page 44), who uses metaphors of fluidity - particularly of the ocean - as a means of symbolizing the slippery, solipsistic rhetoric of the sophists, for water in its becoming is the substance most removed from the eternal stability of the Ideas: his depiction of "an open sea of speeches, beyond all sight of land" makes rather obvious the perceived relationship between the stability of land and the turbulent flux of the sea.

The gendered pronouns in Irigaray's (1991, page 31) writing on the sea are not incidental: "All right, so you want her to signify: you are the being of becoming. But do you make that same statement in return, for her? Do you confide in her: you are the becoming of being?" Women are analogous to becoming, fluidity, materiality, negation - concepts upon which philosophy has built its artifice, and yet has simultaneously forsaken. Thus, whereas Braidotti views the nomadic feminist subject as something-to-come, enabled by and yet exceeding the mobility and difference of postmodern society, Irigaray by contrast views the fluidity of the feminine subject as the very condition of its possibility as the disavowed remainder of the stability of masculinist discourse. One must ask, however, whether there is an illegitimate conflation here between two incommensurable conceptions of fluidity: one a quite literal understanding of fluid mechanics, and the other a metaphorical understanding of the fluidity of feminine identity tied (perhaps somewhat tenuously) to the differentiality of the sexed body. This is, of course, a problem that exists in Deleuze and Guattari's work as well. Another conflation, 
Thomas Sutherland, 'Intensive mobilities: figurations of the nomad in contemporary theory', Environment and Planning D: Society and Space. $32(5): 935-950$.

http://www.envplan.com/abstract.cgi?id=d14027p

however, is made specifically in Braidotti's work - one that I believe to be unwittingly complicit with the dominant subjectivity of post-industrial, digital capitalism - and it is to this that I wish to dedicate the rest of this essay.

\section{New materialism, same old capitalism?}

Although she does not embrace the strategic, mimetic essentialism of Irigaray to quite the same degree, Braidotti does understand sexed and gendered difference as being necessary disjuncts within the formation of identity; for instance, she criticizes Deleuze and Guattari's (1987, page 306) notorious claim that "all becomings begin with and pass through becoming-woman" by observing that "the process of becoming, far from being the dissolution of all identities in a flux where different forms and connections will emerge, may itself be sex-specific, sexually differentiated, and consequently take different forms according to different gendered positions.” (Braidotti 1994, page 121)

Sexual difference, Braidotti (2002, pages 168-169) argues, understood as "the dissymetrical power relations between the sexed subjects," does not call into question the becoming of the individual, but rather, provides the means through which we are able to differentiate the paths and patterns of migration that characterize different flows of becoming - "the extreme affirmation of sexed identity as a way of reversing the attribution of differences in a hierarchical mode... empowers women to act." She does not seek to eliminate sexual difference, nor to transcend the materiality of the body; rather, she wishes to free such categories from the stasis within which they have been frozen. Braidotti (2013, page 38) depicts not a monism of becoming, but a multiplicity of becomings, differentiated through the striating effects of identity production (i.e. territorialization), and as such, nomadic philosophy must distinguish between these "different flows of mutation."

Braidotti's (2002, page 164) justification of this ontology of nomadic desire is based almost entirely upon the claim that in "a historical time when the subject is dismembered and re-located along multiple axes, marked simultaneously by globalization and fragmentation," an era when "critical selfawareness is held in check by the forcefully installed amnesia of changes that are sweeping over us with too much speed and simultaneity," there is a need for a "radical restructuring of the subject as a desiring entity." What this means, following Deleuze and Guattari (1983, page 26), who argue that the "traditional logic of desire is all wrong from the very outset," is that we need to understand desire as a productive force, rather than a symptom of lack, and accordingly seek to comprehend the myriad of ways in which our flows of desiring-production are captured, coded, and territorialized.

It is quite unambiguous that Braidotti (2006b, page 8) considers nomadic subjectivity to be enabled by the purported fluidity of postmodern capitalism, although she does go to lengths to point out that the nomadism of the latter should not be considered synonymous with the former:

the poly-centred, multiple and complex political economy of late postmodernity is nomadic in the sense that it promotes the fluid circulation of capital and of commodities. In this respect, it favours the proliferation of differences, but only within the strictly commercial logic of profit.

A truly nomadic subjectivity, she claims, would be one that rejects this capitalist axiomatic and allow for a genuinely multitudinous production of difference. This is a common theme in Braidotti's philosophy, 
Thomas Sutherland, 'Intensive mobilities: figurations of the nomad in contemporary theory', Environment and Planning D: Society and Space. $32(5): 935-950$.

http://www.envplan.com/abstract.cgi?id=d14027p

this sense that nomadism already exists, and yet is limited in its potential for actualization: as she notes later, "we move about, in the flow of current social transformations, in hybrid, multi-cultural, polyglot, post-identity spaces of becoming," but at the same time, there is "a shortage on the part of our social imaginary, a deficit of representational power;" (page 85) in short, an unwillingness to embrace a representation of radical difference as difference.

Although it would be certainly reasonable to observe that certain identity boundaries - gender and nationality for instance - have been loosened by global capitalism, it would still seem to me to be a worrying conflation of two non-analogous claims to fluidity to argue for a direct causal correspondence between these two observations, not only because there is little evidence that such identities have really been dissolved (as opposed to reconstituted) through these processes, but also because it implies that embracing the aegis of capital would be an effective means for further blurring these boundaries. The assurance that her version of nomadic subjectivity will be "strictly non-profit" (page 8) feels rather empty when her entire conception of fluidity is predicated upon the axiomatization of previously overcoded identities by the movement of capital. It is easy to forget that terms such as "cash flow" and "liquidity" have a history in the finance sector that long predates any widespread utilization within social theory, and that the application of these terms within theories of globalization tends to mirror the self-presentation of global capital by the managerial class that has been responsible for much of its most pernicious effects (Ho 2005).

"The unitary vision of the subject," Braidotti (page 31) contends, "cannot provide an effective antidote to the processes of fragmentation, flows and mutations, which mark our era." This may be true, but why must a new conception of subjectivity so closely mirror that which is imposed upon us by the formation that we in some way seek to change? Why do we even allow these forces to demand of us a new subjectivity? Braidotti's (page 176) answer is that in

a world constituted by flows and mobility, political agency is best served by a subject that is attuned to his or her historicity and is in turn flowing and mobile. This is no blind mimesis, as the cynics are likely to insinuate, but rather a synchronization of inner with outer time.

This, she proclaims, is a Spinozist solution to the problem of finding agency in a world of rapid movement and change - accepting the necessity of the world in order to change it, following Benedict de Spinoza's (1992, page 205) argument that insofar "as the mind understands all things as governed by necessity, to that extent it has greater power over emotions." Yet what if there is no homogeneous outer time with which we can synchronize? What Braidotti is advising, in effect, is that we synchronize ourselves with the literally inapprehensible time of digital media.

The problem with this argument is that there is literally no way in which the human mind or body can properly synchronize with a time measured in fractions of a second - we will always be behind - and as such, it is hard to conceive of how such an attempt might benefit us. Spinoza (page 195) may see freedom as synonymous with necessity, but this is because he a rationalist par excellence - a philosopher of contemplation, rather than reckless action: 
Thomas Sutherland, 'Intensive mobilities: figurations of the nomad in contemporary theory', Environment and Planning D: Society and Space. $32(5): 935-950$.

http://www.envplan.com/abstract.cgi?id=d14027p

there is no rational life without understanding, and things are good only insofar as they assist a man to enjoy the life of the mind. Those things only do we call evil which hinder a man's capacity to perfect reason and to enjoy a rational life.

Given that the temporality of digital capitalism is unlikely to enhance the power of the body or the mind, Spinoza (page 207) - who claims that "[a]s long as we are not assailed by emotions that are contrary to our nature, we have the power to arrange and associate affections of the body according to the order of the intellect" - would surely argue in such circumstances that whilst we need to recognize the ways in which shifting temporalities have affected us, the more important goal is to free ourselves of those sad passions that enslave us, and this would seem less and less likely the more that we depend upon these inhuman temporalities that we have unleashed upon the world. The aim should not be to allow ourselves to be carried along by digital temporality with the hope that it will lead us elsewhere, but to think beyond it - external to it.

Braidotti ends up ontologizing, universalizing, and absolutizing this one particular sense of time under the banner of "becoming," even whilst apparently celebrating the multiplicity of temporalities present at any one point. When she argues that the body consists of "pure flows of energy, capable of multiple variations," with the self - that is, that which is endowed with identity - "anchored in this living matter, whose materiality is coded and rendered in language" (1994, page 165), or that a "radically immanent intensive body is an assemblage of forces, or flows, intensities and passions that solidify in space, and consolidate in time, within the singular configuration commonly known as an 'individual' self," (2006b, page 157) this is surely not simply a historicization - how could it be, when dealing in such terms? Hence, what occurs is that on the one hand she claims to be promoting a nomadic subjectivity as a result of specific historical contingencies, and then at the same time, replicates these very same contingencies in ontological terms.

It is worth acknowledging that the concept of nomadism has already been rigorously critiqued from many distinct perspectives. Norris (1993, page 231), for instance, whose work seeks principally to rescue poststructuralist theory from the epistemological skepticism that is so often ascribed to it, contends that Kant has already anticipated the metaphor of the nomad as it is deployed in Deleuze's philosophy, and uses it to argue for "a process of enlightened reciprocal exchange which abjures the presumptive (authoritarian) appeal to self-evident grounds, but which maintains the possibility of arriving at adequate criteria or validity-conditions for arguments offered in the public sphere of accountable reasons and principles."

Janet Wolff (1993, page 235) criticizes nomadism from a feminist perspective, observing not only that the postmodernist celebration of the death of the grand metanarrative potentially undermines the very premise of feminism itself, but that "the consequent suggestion of free and equal mobility is itself a deception, since we don't all have the same access to the road," with the result that "in a patriarchal culture we are not all, as cultural critics any more than social beings, 'on the road' together." Although she acknowledges the potentially emancipatory value of the vocabulary of mobility, Wolff (page 235) advises caution, for it "also encourages the irresponsibility of flight and misleadingly implies a notion of universal and equal mobility," eliding "the exclusions of a metaphoric discourse of travel." Likewise, Caren Kaplan (1996, pages 89) - observing that according to Deleuze and Guattari's own account, the movement of deterritorialization is always accompanied by a reterritorialization - argues 
Thomas Sutherland, 'Intensive mobilities: figurations of the nomad in contemporary theory', Environment and Planning D: Society and Space. $32(5): 935-950$.

http://www.envplan.com/abstract.cgi?id=d14027p

that such discourse "itself cannot escape colonial discourse," for deterritorialization "colonizes, appropriates, even raids other spaces." Declaring that "Euro-American recourse to the metaphors of desert and nomad can never be innocent or separable from the dominant orientalist tropes in circulation throughout modernity," Caplan (1996, pages 66, 90) observes the "close fit between the mythologized elements of migration (independence, alternative organization to nation-states, lack of opportunity to accumulate much surplus, etc.) and Euro-American modernist privileging of solitude and the celebration of the specific locations associated with nomads."

"As a metaphor," Cresswell (2006, page 54) argues, "the nomad repeats centuries of Western romanticization of the non-Western other. It simultaneously reproduces representational strategies of colonialism under the guise of the nonrepresentational." The fetishization of the nomadic identity is concerning, firstly because one might surmise that the true nomads of our age - refugees, displaced peoples, and the mobile working poor - would in most cases desire nothing more than the surety of a somewhat fixed, static identity, and at present have little ability to take advantage of the multiplicitous interconnectivity of which Braidotti speaks. Such accounts, remarks Clemens (2003, page 174), "oscillate undecidably between considering such 'movement' as a theoretico-political category (registering a dire situation of, say, migrant displacement) and enthusiastically affirming it as a utopian figure.” Likewise, argues Slavoj Žižek (2006, page 390):

the problem with 'abstract' universal terms like hybridity and nomadic subjectivity is that they tend to iron out, to render invisible, the antagonism that cuts across their content: when hybridity covers the globetrotting academic as well as the refugee from a war-torn country, it does something similar to obfuscating the gap that separates starving from dieting.

There is something terribly cosmopolitan about the figure of the Deleuzian nomad, and this remains patently clear within Braidotti's work. Mobility can certainly be an enormously liberating capacity, but there is significant risk in idealizing it as a political and ethical imperative in a society where mobility is often something that is imposed rather than chosen, and the principles of flexibility and adaptability are code-words for the increasing precariousness of labour.

But secondly, it is problematic because the very image of the postmodern nomad - who is formed through "[m]ovement and speed, lines of sedimentation and lines of flight" (Braidotti 2013, page 189) - feeds into the restless, fluid subjectivity that permits both the continued circulation of capital and the endless cycles of obsolescence and renewal proffered by digital technologies: "the transformation of the dialectic of use-value and exchange-value into a third term - the spectre of an empty cycle of circulation moving at the digital speed of degree-zero and in circuits of zero-time," as Arthur Kroker (2004, page 129) puts it. Such perceived fluidity is not the reality of capital, for the latter's expansion relies upon crisis and discontinuity as much as ineluctable growth, but rather, it is the projected mythology of capital. What Deleuze and Guattari's later work acknowledges is that there is a disjunct between the projected image of capital as limit-case and the instantiation of capitalism as a specific socio-economic structure. Capital, in the former sense truly is a pure becoming, in that it is entirely abstract: it does not exist in itself, but only as the perpetually deferred actualization of an always real, but always virtual telos; it is the nightmarish premonition of a world stripped of all human meaning and value. The myth of capital can never truly be realized, as it forgets the necessity of that 
Thomas Sutherland, 'Intensive mobilities: figurations of the nomad in contemporary theory', Environment and Planning D: Society and Space. $32(5): 935-950$.

http://www.envplan.com/abstract.cgi?id=d14027p

which exists outside of it. Capital, which attempts to dissolve the being of things through an axiomatization of value, requires not only the continual presence of a being to be abstracted in such a fashion, but in fact produces such a being through the continual positing of its own limits, the latter of which is capitalism.

To put this more concretely, the movement of capital as potentiality is in effect the final cause of capitalism as a concrete entity. The effects of capital are only actualized through the reterritorializing processes of capitalism, and the state apparatuses that support it:

[i]n contrast with the ancient empires that carried out transcendent overcodings, capitalism functions as an immanent axiomatic of decoded flows (of money, labor, products). National States are no longer paradigms of overcoding but constitute the "models of realization" of this immanent axiomatic. In an axiomatic, models do not refer back to a transcendence; quite the contrary. It is as if the deterritorialization of States tempered that of capital and provided it with compensatory reterritorializations (Deleuze and Guattari 1994, page 106).

As Wendy Brown (2006) observes in the context of the United States, neoliberalism, an ideology which in effect seeks to erase national borders whilst simultaneously subsuming all relations and processes into the axiomatic of money, is actually able to perpetuate itself through the production of a neoconservative counter-ideology, which strives to reestablish borders and increase state power through religious and nationalist discourse. What needs to be stated therefore, is that whilst the particulars may shift, capitalism has not and cannot bring the world into flux, as "deterritorialization on a stratum always occurs in relation to a complementary reterritorialization." (Deleuze and Guattari 1987: 60) Every flow requires a corresponding agent of fixity. Even if capitalism did provide the means for such deterritorialization though, there is no reason to assume that this would be emancipatory, given that the deterritorialization and decoding of capital offers no sense of the agency presumed in discussions of nomadic identity, but instead, transfers the sovereignty of the individual to that inhuman leviathan of exchange value.

I am not arguing for absolute stasis anymore than I am arguing for absolute becoming; instead, I am attempting to call into question the very dichotomy that would speak of "the discipline of being and the freedom of becoming," as Manuel Castells (2009: 414) would have it, as if the limits of being are not in themselves conducive to agency. Braidotti (1994, page 29) puts forward the claim that "nomadic-thinking is a minority position," and yet, it would seem to me that this fundamentally Deleuzian notion of ontological surplus and productivity is not at all subversive in relation to the demands of the postmodern, post-industrialized economy, but rather, is premised upon the very same assumptions that allow the continued perpetuation of the latter's self-projected mythology. As Jean Baudrillard (1994, page 140) once put it:

a whole liberatory phantasmagoria is drawn in opposition to the constraints of modern society, a representation of nature and of beasts as savagery, as the freedom to 'fulfill all needs,' today 'of realizing all his desires' - because modern Rousseauism has taken the form of the indeterminacy of drive, of the wandering of desire and of the nomadism of infinitude 
Thomas Sutherland, 'Intensive mobilities: figurations of the nomad in contemporary theory', Environment and Planning D: Society and Space. $32(5): 935-950$.

http://www.envplan.com/abstract.cgi?id=d14027p

- but it is the same mystique of unleashed, noncoded forces with no finality other than their own eruption.

The basic assumption of Deleuzian nomadism - that for every false difference and false becoming that we perceive through the reification of representational categories, there is a limitless, creative, authentic becoming underpinning, and which can be harnessed in order to move beyond these reifications - completely elides the possibility that it is the very same hypothetical guarantee that justifies the unsustainable growth of the post-industrial society, which is anything but immaterial. How, we must ask, does nomadism challenge the "commercialization of planet Earth in all its forms, through a series of inter-related modes of appropriation," (Braidotti 2013, page 7) when it would seem to reinforce an ideology of excess that not only provides the political justification for such appropriation, but underwrites the metaphysical assurance that such appropriation is sustainable? Why would we halt these exploitative processes when we are told that there is always a surplus lying in wait?

\section{Conclusion}

An ontology of affirmative desire - that is, one in which desire is posited as a vital impetus - is almost inevitably one that absolutizes productivity as the telos of all beings in terms remarkably homologous to the management principles of post-industrial capitalism: to quote Baudrillard (1975, page 19) once again, "it is no longer a question of 'being' oneself but of 'producing' oneself, from conscious activity to the primitive 'productions' of desire." Vitalism of this kind, which is supposed to undermine the dominance of capital by positing a form of creative desire that necessarily exists as a surplus external to the capitalist axiomatic, fails to account for the way in which this very notion of excess productivity mirrors the reliance of capital upon the creation of surplus-value: capital actually relies upon a continually increasing productivity in order to produce that surplus for it to capture and axiomatize (Noys 2011).

"When today's subjectivity is celebrated as rootless, migratory, nomadic, hybrid, and so on," asks Žižek (2006, page 194), "does not digitalization provide the ultimate horizon of this migration, that of the fateful shift of hardware into software?" In the face of digital capitalism, and its ever-growing demand for speed and productivity, it would seem to me that what is needed is not Deleuze's "manic defense against negativity," as Judith Butler (2004, page 198) describes it, but instead, a form of critique premised upon the necessity of limits not as a barrier to be overcome, but as a potentiality to be stored and utilized: Žižek (1999, page 431) once more remarks quite accurately, "it is much more crucial to focus on what remains the same in this global fluidity and reflexivity, on what serves as the very motor of this fluidity." The theories of nomadism discussed in this essay may seek to challenge the assumptions of postmodern, digital capitalism, but in the end, such aims are undermined by the very metaphor of fluidity itself, which naturalizes and ontologizes the technically enabled movement of capital in the terms of an ineluctable and absolute becoming. These concepts are not neutral, but are tied to a discourse of administration the interests of which lie in attempting to justify and normalize the teleology of digital capitalism.

To put it bluntly: becoming is not radical; becoming is necessary. Absolute becoming is likewise not radical, and it is also, by virtue of its very claim to absoluteness, not absolute, for to be absolute is to be nothing else but stable. Change with a purposive end can be beneficial, even perhaps emancipatory, but change for the sake of change - "movements without subjects, roles without actors" (Deleuze 1994, 
Thomas Sutherland, 'Intensive mobilities: figurations of the nomad in contemporary theory', Environment and Planning D: Society and Space. $32(5): 935-950$.

http://www.envplan.com/abstract.cgi?id=d14027p

page 271) - can be overwhelming and oppressive, so let us not conflate the two. When we speak of the contingencies of mobility, we should not risk blurring such a concept with the metaphysical category of becoming. "Time," argues Serres (1995, page 97), "is still and always a chaos, a noise, and a disorder": true becoming is never homogeneous, nor empty in the manner of the formalism of the fluid, nomadic subject; on the contrary, it can only represent the infinitely plural temporalities of the universe in its infinite complexity. "Only the yearning for sustainable futures can construct a liveable present," declares Braidotti (2006a, page 206), a statement with which I could not agree more. The question is, though, can we keep up with the costs of a perpetually nomadic subjectivity?

\section{Bibliography}

Baudrillard J, 1975 The Mirror of Production translated by M Poster (Telos Press, St Louis)

Baudrillard J, 1994 Simulacra and Simulation translated by SF Glaser (The University of Michigan Press, Ann Arbor)

Bergson H, 1911 Creative Evolution translated by A Mitchell (Dover, Mineola)

Braidotti R, 1994 Nomadic Subjects: Embodiment and Sexual Difference in Contemporary Feminist Theory (Columbia University Press, New York)

Braidotti R, 2002 Metamorphoses: Towards a Materialist Theory of Becoming (Polity Press, Cambridge and Malden)

Braidotti R, 2006a, "Posthuman, All Too Human: Towards a New Process Ontology" Theory, Culture \& Society 23 197-208.

Braidotti R, 2006b Transpositions (Polity Press, Cambridge and Malden)

Braidotti R, 2013 The Posthuman (Polity Press, Cambridge and Malden)

Brown W, 2006, “American Nightmare: Neoliberalism, Neoconservatism, and De-Democratization” Political Theory 34 690-714.

Butler J, 2004 Undoing Gender (Routledge, New York and London)

Castells M, 2009 Communication Power (Oxford University Press, Oxford)

Clemens J, 2003 The Romanticism of Contemporary Theory (Ashgate, Aldershot)

Cresswell T, 2006 On the Move: Mobility in the Modern Western World (Routledge, London and New York)

Cresswell T, 2010, "Towards a politics of mobility" Environment and Planning D: Society and Space 28 17-31 
Draft version - please do not cite

Final version published as:

Thomas Sutherland, 'Intensive mobilities: figurations of the nomad in contemporary theory', Environment and Planning D: Society and Space. $32(5): 935-950$.

http://www.envplan.com/abstract.cgi?id=d14027p

Cresswell T, Martin C, 2012, "On Turbulence: Entanglements of Disorder and Order on a Devon Beach" Tijdschrift voor economische en sociale geografie 103 516-529

Curd P, 2011 A Presocratics Reader: Selected Fragments and Testimonia (Hackett, Indianapolis and Cambridge)

Deleuze G, 1994 Difference and Repetition translated by P Patton (Continuum, London and New York)

Deleuze G, Guattari F, 1983 Anti-Oedipus translated by R Hurley, M Seem, HR Lane (Continuum, London and New York)

Deleuze G, Guattari F, 1987 A Thousand Plateaus translated by B Massumi (Continuum, London and New York)

Deleuze G, Guattari F, 1994 What is Philosophy? translated by H Tomlinson and G Burchell (Columbia University Press, New York)

Elliott A, Urry J, 2010 Mobile Lives (Routledge, Abingdon and New York)

Hannan K, Sheller M, Urry J, 2006, "Editorial: Mobilities, Immobilities and Moorings” Mobilities 11 22

Hardt, M, Negri, A, 2000 Empire (Harvard University Press, Cambridge)

Ho K, 2005, “Situating Global Capitalisms: A View from Wall Street Investment Banks" Cultural Anthropology 20 68-96

Holland E, 2011 Nomad Citizenship: Free-Market Communism and the Slow-Motion General Strike (University of Minnesota Press, Minneapolis)

Kant I, 1998 Critique of Pure Reason translated by P Guyer, AW Wood (Cambridge University Press, Cambridge)

Kroker A, 2004 The Will to Technology \& the Culture of Nibilism: Heidegger, Nietzsche, \& Marx (University of Toronto Press, Toronto)

Irigaray L, 1985 This Sex Which is Not One translated by C Porter, C Burke (Cornell University Press, Ithaca)

Irigaray L, 1991 Marine Lover of Friedrich Nietzsche translated by GC Gill (Columbia University Press, New York)

Irigaray L, 1999 The Forgetting of Air in Martin Heidegger translated by MB Mader (The Athlone Press, London) 
Draft version - please do not cite

Final version published as:

Thomas Sutherland, 'Intensive mobilities: figurations of the nomad in contemporary theory', Environment and Planning D: Society and Space. $32(5): 935-950$.

http://www.envplan.com/abstract.cgi?id=d14027p

Kaplan C, 1996 Questions of Travel: Postmodern Discourses of Displacement (Duke University Press, Durham)

Nietzsche F, 2005 The Anti-Christ, Ecce Homo, Twilight of the Idols and Other Writings translated by J Norman (Cambridge University Press, Cambridge)

Norris C, 1993 The Truth About Postmodernism (Blackwell, Oxford and Cambridge)

Noys B, 2010, The Persistence of the Negative: A Critique of Contemporary Continental Theory (Edinburgh University Press, Edinburgh)

Noys B, 2011, “'Grey in Grey’: Crisis, Critique, Change” Journal of Critical Globalisation Studies 4 4560

Plato, 2005 Protagoras and Meno (Penguin, London)

Serres M, 1995 Genesis translated by G James and J Nielson (The University of Michigan Press, Ann Arbor)

Serres M, 2000 The Birth of Physics translated by J Hawkes (Clinamen Press, Manchester)

Spinoza B, 1992 Ethics, Treatise on the Emendation of the Intellect, and Selected Letters (Hackett, Indianapolis and Cambridge)

Steinberg PE, 2013, "Of other seas: metaphors and materialities in maritime regions" Atlantic Studies: Global Currents 10 156-169

Virilio P, 2008 Open Sky translated by J Rose (Verso, London)

Wolff J, 1993, "On the road again: Metaphors of travel in cultural criticism" Cultural Studies 7 224239

Žižek S, 1999 The Ticklish Subject: The Absent Centre of Political Ontology (Verso, London)

Žižek S, 2006 The Parallax View (The MIT Press, Cambridge) 